\title{
Effect of Growth Stage Moisture Stress on Common Bean (Phaseolus Vulgaris L.) Yield and Water Productivity at Jimma, Ethiopia
}

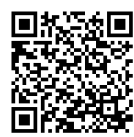

\author{
Robel Admasu*, Addisu Asefa and Minda Tadesse \\ Jimma Agricultural Research Center, Ethiopia
}

Submission: December 19, 2018; Published: January 10, 2019

*Corresponding author: Robel Admasu, Jimma Agricultural Research Center, Jimma, Ethiopia

\begin{abstract}
Water stress is a major crop production constraint for common bean (Phaseolus vulgaris L.). This study investigated the response of common bean (Phaseolus vulgaris L.) to moisture stress at different growth stages for yield and water productivity under sub-humid climate conditions over a three-year period. A field experiment was conducted at Jimma Agricultural Research. A randomized complete block design with three replications was used. fifteen treatments which combined and imposed at four growth stages were used. The combined result indicated that there were a significant variation among treatments for yield, above ground dry biomass and water productivity. The yield of common bean was significantly affected due to moisture stress imposed at different growth stages. Accordingly, the highest was obtained from irrigating all growth stage $\left(2087.7 \mathrm{~kg} \mathrm{ha}^{-1}\right)$ followed by irrigating all stage except initial stage $\left(1902.2 \mathrm{~kg} \mathrm{ha}^{-1}\right)$. In contrast, imposing moisture stress at three growth stage except initial stage was recorded the lower yield relatively, which followed by irrigating only at maturity stage. The results revealed that water stress imposed at development and mid-season stages reduced the yield significantly. The water productivity was ranged from $(0.34 \mathrm{~kg}$ $\left.\mathrm{m}^{-3}\right)$ at optimum irrigation water application to $\left(1.33 \mathrm{~kg} \mathrm{~m}^{-3}\right)$ at stress at development, mid-season and late season stage. Therefore, imposing moisture stress during the two growth stages except initial and maturity treatments had significantly reduce the yield of common bean, and also for enhancement of water productivity without a significant yield penalty depriving irrigation at initial and maturity stage recommended.

Keywords: Growth stage; Water productivity; Common bean; Moisture stress
\end{abstract}

\section{Introduction}

Agriculture is accountable for the largest extraction of water and thus considered the chief 'culprit' under conditions of local absolute scarceness COAG [1]. Water is vital for all socioeconomic development and for maintaining healthy ecosystems. As population increases the utilization of groundwater and surface water for the domestic, industrial sectors and agriculture exaggerate, leading to tensions, conflicts between users, and extreme pressure on the environment (UN-WATER, 2006). Water is one of the most useful components for crop production and found abundantly in south west region of Ethiopia. However, due to lack of effective water management practices it became a scarce resource. As water scarcity intensified in the region, strategies like deficit irrigation and depriving irrigation at some growth stage without significantly reducing the crop yield by improving water productivity must be adopted.

In the context of improving water productivity, there is a growing interest in depriving irrigation at some growth stage, an irrigation practice whereby water supply is restricted, and stress is allowed with minimal effects on yield. Under conditions of scarce water supply and drought, deficit irrigation can lead to greater economic gains by maximizing yield per unit of water. Therefore, it is important to see what level of stress at different growth stages result in high water use efficiency. This enables irrigators to know not only a critical growth stage but also the optimum magnitude of stress to be imposed. Common bean (Phaseolus vulgaris L.) is one of the widely cultivated plants. It is considered one of the most important grains for human alimentation and is planted worldwide on approximately 26 million hectares Emam [2]. Like other plants, the development and productivity of beans is adversely affected by biotic and abiotic stress factors Jaleel [3]. With the evolving phenomena of climate change, it is anticipated that these stress factors will exert increasing impacts on crop productivity Man [4]. Among the abiotic factors, water stress is perhaps the major factor limiting crop production worldwide Jones \& Corlett [5]. There are reports that common bean is susceptible to drought stress or water deficit and it has been reported accelerated maturity of crop along with reducing grain yield and mean weight of hundred seeds following water stress, have been reported Nielsen [6] and Molina [7]. Furthermore, common bean cultivar has reported to respond differently to soil moisture stress depending on the severity of water stress Boutraa [8]. But there is no sufficient information on what growth stage the crop is susceptible for moisture stress. Therefore, information on depriving irrigation at different growth stage on yield and water productivity is useful for effective water 
management. The purpose of this study was to identify specific growth stages of the common bean crop at which the plant is less sensitive to water stress and irrigation can be omitted without a significant decrease on a final yield by improving water productivity.

\section{Materials and Methods}

\section{Description of the experimental area}

Table 1: Treatments combination.

\begin{tabular}{|c|c|}
\hline Number & Treatments \\
\hline 1 & Irrigate all growth stages (Check) \\
\hline 2 & Irrigate all stages except initial stage \\
\hline 3 & Irrigate all stages except development stage \\
\hline 4 & Irrigate all stages except mid-season stage \\
\hline 5 & Irrigate all stages except maturity stage \\
\hline 6 & Irrigate all stages except initial and development stages \\
\hline 7 & Irrigate all stages except initial and mid-season stage \\
\hline 8 & Irrigate all stages except initial and maturity stages \\
\hline 9 & Irrigate all stages except development and mid-season \\
\hline 10 & Irrigate all stages except development and maturity stages \\
\hline 11 & Irrigate all stages except mid-season and maturity stages \\
\hline 12 & Irrigate only at maturity stage \\
\hline 13 & Irrigate only mid-season stage \\
\hline 14 & Irrigate only development stage \\
\hline 15 & Irrigate only initial stage \\
\hline
\end{tabular}

The experiment was conducted at Jimma Agricultural research center in south west Ethiopia for the consecutive three years. The Jimma Agricultural research center is located at 7046' N latitude, 3600 ' E longitude, and at an altitude of $1753 \mathrm{~m}$ above sea level. The center receives an average annual rainfall of about $1530 \mathrm{~mm}$ with monthly mean maximum and minimum temperatures of $25.90 \mathrm{C}$ and $11.3^{\circ} \mathrm{C}$, respectively.

\section{Experimental materials, design and management}

A field experiment was carried out in three seasons of 2016 and 2018. This experiment was laid out in RCBD with three replications. The treatments which are presented in Table 1 consisted of fourteen soil moisture stress levels and a check which imposed at four growth stages. Each individual plot had area of $4 \mathrm{mX} 4 \mathrm{~m}=16 \mathrm{~m}^{2}$, which consists of 6 rows. Goberasha common bean variety (Phaseolus vulgaris L.) was used as seed source. The recommended spacing of 60 and $10 \mathrm{~cm}$ between row and plant was employed. Each experimental treatment was fertilized with recommended fertilizer application, that was $100 \mathrm{~kg} / \mathrm{ha}$ and $100 \mathrm{~kg} / \mathrm{ha}$ of DAP and Urea, respectively. All cultural practices were done to all treatments in accordance to the recommendation made for the area. Irrigation water was applied as per the treatment to refill the crop root zone depth close to field capacity. The net depth of irrigation at each growth stage for all treatments presented in Table 2 below.

\section{Data collected}

Yield and growth parameter were recorded, and the treatments were compared based on grain yield and growth parameter, which includes plant height, above ground biomass and grain yield. Also, water productivity of the crop was estimated. Grain yield was calculated by harvesting the total number of plants in the net plot $\left(4.5 \mathrm{~m}^{2}\right)$ and grain yield per plot was measured using electronic balance and then adjusted to $10.0 \%$ moisture and converted to hectare basis. Above ground biomass was determined by harvesting all the plants from the net plot area at physiological maturity and weighed after sun drying to a constant weight and converted to hectare basis. The water productivity was calculated by the ratio of harvested yield per total water used. Mathematically it was determined using the following equation as described by Michael [9].

$$
W p=\frac{(\text { Harvested grain yield })}{(\text { Total water used })}
$$

The yield response factor Ky is the slope of the relative yield reduction versus relative evapotranspiration deficit as described by Doorenbos and Kassam 1979. The relationship is expressed mathematically (Equation (2)) and yield response factor is calculated as;

$$
\left(1-\frac{Y_{a}}{Y_{m}}=K_{y}\left(1-\frac{E T_{a}}{E T_{m}}\right)\right.
$$

Where: Ya = actual yield $(\mathrm{kg} / \mathrm{ha}), \mathrm{Ym}=$ maximum yield $(\mathrm{kg} /$ ha), ETa = actual evapotranspiration $(\mathrm{mm}), \mathrm{ETm}=$ maximum evapotranspiration $(\mathrm{mm})$, and $\mathrm{Ky}=$ yield response factor.

The data were statistically analyzed combined for all years by SAS software. SAS software version 9.2 for windows was used for analysis SAS Institute [10]. Whenever the treatment effects were found significant, GLM test at 1 and $5 \%$ was performed to assess significant difference among treatments means.

\section{Economic evaluation}

To assess the costs and benefits associated with different treatments the partial budget technique as described by CIMMYT [11] was applied on the yield results. Economic analysis was done using the prevailing market prices during experimentation and at the time the crop was harvested. All costs and benefits were calculated on hectare basis in Ethiopian Birr (ETB/ha). The different costs of the experiment that includes cost for irrigation water and labor cost to irrigate were the variable costs among the different treatments. The adjusted yield was obtained by reducing the average yield by $10 \%$ as indicated in CIMMYT [11]. The average cost the local people were paying for daily labor was 26.00 Birr per day. The farm gate price of common bean during the harvesting time was $18 \mathrm{Birr} / \mathrm{kg}$ and the price of irrigation water was taken 1.00 Birr per $10 \mathrm{~m}^{3}$ of water (own assumption). Some of the concepts used in the partial budget analysis are gross benefit, total variable cost and net benefit. The gross benefit was obtained as the product of the real price and the adjusted 
grain yield of common bean for each treatment. The Dominant analysis procedure as detailed in CIMMYT [11] was used to select potentially profitable treatments from the range that was tested. The selected and discarded treatments using this technique are referred to as undominated and dominated treatments, respectively. The undominated treatments were ranked from the lowest to the highest variable cost. For each pair of ranked treatments, a \% marginal rate of return (MRR) was estimated.

\section{Result and Discussion}

\section{Plant height}

The analysis of variance revealed that there is no a significant $(\mathrm{P}<0.05)$ difference among treatments due to moisture deficit at different growth stage. Even though, the maximum plant height was obtained from irrigating all growth stages $(48.0 \mathrm{~cm})$ followed by irrigating all growth stage except initial stage $(47.6 \mathrm{~cm})$ and irrigating all stage except maturity stage $(46.3 \mathrm{~cm})$ (Table 2$)$. The minimum plant height was obtained from irrigating at initial stage only $(42.6 \mathrm{~cm})$ (Table 2). The plant height decrease was of high magnitude for moisture stress at vegetative and flowering stages and this reduction could be due to reduction in moisture content at root zone which reduce leaf elongation and leaf expansion together with reduced photosynthesis activity that leads to the inhibition of the plant growth. The finding is in line with Ntukamazina [12] and Amir [13] who reported that plant height is reduced when the moisture stress occurs at development (vegetative) and mid-season (flowering) stages. Such reduction in plant height was reported for maize Elias [14] \& Robel [15], sorghum Ahmad [16] and onion Metwally [17].

\section{Above ground dry bio-mass}

Shoot biomass accumulation is considered an important trait to attain high seed yield in grain legumes. Moisture stress at different growth stages had a highly significant influence $(p<0.001)$ on common bean above ground dry biomass production. Above ground dry weight was decreased as increased of water stress levels (Table 2). Maximum above ground dry biomass was obtained from irrigated all growth stage (6.0t ha $\left.\mathrm{h}^{-1}\right)$ followed by irrigated all stage except initial stage $\left(5.9 \mathrm{t} \mathrm{ha}^{-1}\right)$ and irrigated all stage except maturity (5.6t ha-1) (Table 2). The minimum was obtained from irrigating only initial stage $\left(4.0 \mathrm{t} \mathrm{ha}^{-1}\right)$ followed by irrigating only maturity stage $\left(4.1 \mathrm{t} \mathrm{ha}^{-1}\right)$ (Table 2$)$. From the present study, as a moisture stress occur at development and midseason stages the above ground dry biomass reduced significantly. This result indicates that moisture is an essential influence for shoot development. Greater accumulation of plant biomass is an important input to assure total translocation of photosynthate materials to seed. Emam [2] and Rosales-Serna [18] also reported that plant dry weight was decreased significantly by increasing water stress. Barrios [19] reported that leaf dry weight of common beans reduced when plants are exposed to drought stress.

\section{Grain yield}

Highly significant differences were observed among water stress treatments for grain yield (Table 2). The over years analysis of mean grain yield indicated that irrigating during all four growth stages gave a maximum grain yield (2087.7 K. g ha-1) followed by irrigating all stages except initial stage (1902.5Kg ha-1). However, the minimum grain yield was obtained from irrigating

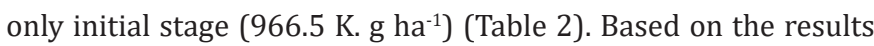
from the present study, deficit irrigation strategy may focus on withholding water supply at early plant growth and maturity stages of common bean. These results are consistent with the findings of Ambachew [20] and Darkwa [21]. They observed that, the late flowering and pod setting stages appear to be the most sensitive stages to soil moisture stress. According to the present study, the reduction of grain yield in water stress at development and mid-season stage as compared to the rest treatments, may have been attributed to a lower percentage of pods formed due to flower abscission and embryo abortion when drought occurred at flowering and pod filling growth stages. Such reduction in grain yield as a moisture stress occur at development (flowering) and mid-season (pod filling) stages was reported for maize Robel [15], onion R.G. Bhagyawant [22] \& Temesgen [23] and soybean Yanqi [24]. In addition, Liu [25] reported that early seed development is extremely vulnerable to drought stress, mainly because it involves several processes that are highly sensitive to changes in plant water status. The ability of crops to partially recover the effect of early water stress has also been observed in other studies Kirda [26]. These studies revealed that under limited water condition, it is better to start by subjecting the crops to stress early in the season. By doing so, the crop adapts to limited watering conditions with the stress not being severely concentrated in any one time period.

\section{Water productivity}

Water productivity improved either by enhancing the yield (nominator) or reducing the water application (denominator). From the stand point of resources conservation, it is important to save as much water as the consequence on economic return is acceptable. It means producing more with less water. Moisture stress at different growth stage had a significant $(\mathrm{p}<0.001)$ influence on water productivity. As can be seen from Table 2 , the water productivity ranged from $0.34 \mathrm{Kg} \mathrm{m}^{-3}$ under full irrigation to $1.33 \mathrm{Kg} \mathrm{m}^{-3}$ irrigating only initial stage. The maximum water productivity is obtained from irrigating only initial stage (1.33 $\left.\mathrm{K} . \mathrm{g} \mathrm{m}^{-3}\right)$ followed by irrigating only maturity stage $\left(0.80 \mathrm{Kg} \mathrm{m}^{-3}\right)$ (Table 2). Whereas, the minimum is obtained from full irrigation treatment $\left(0.34 \mathrm{Kg} \mathrm{m}^{-3}\right)$ (Table 2$)$. Although irrigating only initial stage seem to result highest water productivity due to high water savings, the yield reduction is also high. Such tradeoff, higher water productivity for lower yield, should be carefully interpreted. Acceptable level of water saving and hence water productivity is the highest value level that can be achieved without significant reduction in yield. As summarized by Ali [27], attaining higher yields with increased water productivity is only economical when the increased gains in crop yield are not offset by increased costs of other inputs. Consequently, the intention of deficit irrigation is to improve yield and water productivity by efficiently managing agricultural water. 


\section{International Journal of Environmental Sciences \& Natural Resources}

Table 2: Effect of moisture stress at different growth stages on agronomic performance of common bean.

\begin{tabular}{|c|c|c|c|c|}
\hline Treatment & Grain Yield (K. $\mathrm{g} \mathrm{ha}^{-1}$ ) & Biomass Yield ( $\left.\mathrm{t} \mathrm{ha}^{-1}\right)$ & Plant Height (Cm) & Water Productivity $\left(\mathrm{K}_{\mathrm{g} \mathrm{m} \mathrm{m}}{ }^{-3}\right)$ \\
\hline Irrigate all growth stages (Check) & $2087.7 \mathrm{a}$ & $6.0 \mathrm{a}$ & 48.0 & $0.34 \mathrm{e}$ \\
\hline Irrigate all stages except initial stage & $1902.2 \mathrm{ab}$ & $5.9 \mathrm{ab}$ & 47.6 & $0.36 \mathrm{e}$ \\
\hline $\begin{array}{l}\text { Irrigate all stages except development } \\
\text { stage }\end{array}$ & $1553.5 \mathrm{de}$ & $4.9 \mathrm{~d}$ & 44.0 & $0.36 \mathrm{e}$ \\
\hline $\begin{array}{l}\text { Irrigate all stages except mid-season } \\
\text { stage }\end{array}$ & $1554.0 \mathrm{de}$ & $4.7 \mathrm{e}$ & 43.8 & $0.37 \mathrm{e}$ \\
\hline $\begin{array}{l}\text { Irrigate all stages except maturity } \\
\text { stage }\end{array}$ & $1892.7 \mathrm{bc}$ & $5.6 c$ & 46.3 & 0.41 de \\
\hline $\begin{array}{l}\text { Irrigate all stages except initial and } \\
\text { development stages }\end{array}$ & 1398.9de & $4.7 \mathrm{e}$ & 45.7 & $0.36 \mathrm{e}$ \\
\hline $\begin{array}{l}\text { Irrigate all stages except initial and } \\
\text { mid-season stage }\end{array}$ & 1425.3de & $4.9 \mathrm{~d}$ & 45.2 & $0.53 \mathrm{~cd}$ \\
\hline $\begin{array}{l}\text { Irrigate all stages except initial and } \\
\text { maturity stages }\end{array}$ & $1873.7 \mathrm{bc}$ & $4.5 \mathrm{f}$ & 45.0 & $0.39 \mathrm{e}$ \\
\hline $\begin{array}{l}\text { Irrigate all stages except development } \\
\text { and mid-season stages }\end{array}$ & $1135.7 \mathrm{gh}$ & $4.2 \mathrm{~h}$ & 44.4 & $0.62 \mathrm{c}$ \\
\hline $\begin{array}{l}\text { Irrigate all stages except development } \\
\text { and maturity stages }\end{array}$ & 1366.1ef & $4.2 \mathrm{~h}$ & 43.4 & $0.37 \mathrm{e}$ \\
\hline $\begin{array}{l}\text { Irrigate all stages except mid-season } \\
\text { and maturity stages }\end{array}$ & 1464.8de & $4.5 \mathrm{f}$ & 46.0 & $0.60 \mathrm{~cd}$ \\
\hline Irrigate only at maturity stage & $1058.7 \mathrm{gh}$ & $4.1 \mathrm{hi}$ & 44.1 & $0.80 \mathrm{~b}$ \\
\hline Irrigate only mid-season stage & 1127.8gh & $4.4 \mathrm{fg}$ & 46.0 & $0.36 \mathrm{e}$ \\
\hline Irrigate only development stage & $1227.3 \mathrm{fg}$ & $4.4 \mathrm{fg}$ & 44.0 & $0.61 \mathrm{~cd}$ \\
\hline Irrigate only initial stage & $966.5 \mathrm{~h}$ & $4.0 \mathrm{i}$ & 42.6 & $1.33 \mathrm{a}$ \\
\hline LSD at 0.01 & 209.23 & 0.11 & ns & 0.142 \\
\hline $\mathrm{CV} \%$ & 15.22 & 16.88 & 10.26 & 18.93 \\
\hline
\end{tabular}

\section{Yield response to water stress}

The magnitude of Ky value indicates the sensitivity of the irrigation protocol for water deficit and subsequent yield decreases. The highest Ky was obtained from irrigating all stage except initial stage followed by irrigating all stage except development and irrigation except initial and development stage. Whereas, the minimum was obtained from irrigating all stage except initial and maturity stage (Table 3 ). From the current finding, development and mid-season stage (flowering and pod setting) is the most sensitive to moisture stress and the water Table 3: The yield response factor (Ky) of common bean.

\begin{tabular}{|c|c|c|c|c|c|}
\hline Treatments & Yield (K. g/ha) & ETa $\left(\mathrm{m}^{3} / \mathrm{ha}\right)$ & $1-\mathrm{Ya} / \mathrm{Ym}$ & 1 - ETa/ETm & Ky \\
\hline Irrigate all stage (control) & 2087.7 & 6458 & 0.00 & 0.00 & - \\
\hline Irrigate all stages except initial stage & 1902.2 & 5973 & 0.09 & 0.08 & 1.18 \\
\hline Irrigate all stages except maturity stage & 1892.7 & 5453 & 0.09 & 0.16 & 0.60 \\
\hline Irrigate all stages except initial and maturity stages & 1873.7 & 4968 & 0.10 & 0.23 & 0.44 \\
\hline Irrigate all stages except development stage & 1553.5 & 4923 & 0.26 & 0.24 & 1.08 \\
\hline Irrigate all stages except initial and development stages & 1398.9 & 4438 & 0.33 & 0.31 & 1.05 \\
\hline Irrigate all stages except development and maturity stages & 1366.1 & 3918 & 0.35 & 0.39 & 0.88 \\
\hline Irrigate only mid-season stage & 1127.8 & 3433 & 0.46 & 0.47 & 0.98 \\
\hline Irrigate all stages except mid-season stage & 1554 & 3025 & 0.26 & 0.53 & 0.48 \\
\hline Irrigate all stages except initial and mid-season stage & 1425.3 & 2540 & 0.32 & 0.61 & 0.52 \\
\hline Irrigate all stages except mid-season and maturity stages & 1464.8 & 2220 & 0.30 & 0.66 & 0.45 \\
\hline
\end{tabular}

shortage occur at this stage will reduce the yield significantly. The relationship between relative yield decrease (1-Ya/Ym) and relative evapotranspiration deficit (1-ETa/ETm) was not linear as shown in Figure 1. The result of this experiment was almost same with that of the experiment by Bustomi Rosadi [28] on soybean. The result showed that only those treatments with a lower crop yield response factor $(\mathrm{Ky}<1.0)$ can generate significant savings in irrigation water through deficit irrigation Kirda [29]. According to Kirda [29], the Ky value for field crops goes from 0.2 to 1.15 which agrees with the reported result. 
International Journal of Environmental Sciences \& Natural Resources

\begin{tabular}{|c|c|c|c|c|}
\hline Irrigate only development stage & 1227.3 & 1535 & 0.41 \\
\hline Irrigate all stages except development and mid-season stages & 1135.7 & 1490 & 0.76 & 0.46 \\
\hline Irrigate only at maturity stage & 1058.7 & 1005 & 0.77 \\
\hline Irrigate only initial stage & 966.5 & 485 & 0.49 & 0.54 \\
\hline
\end{tabular}

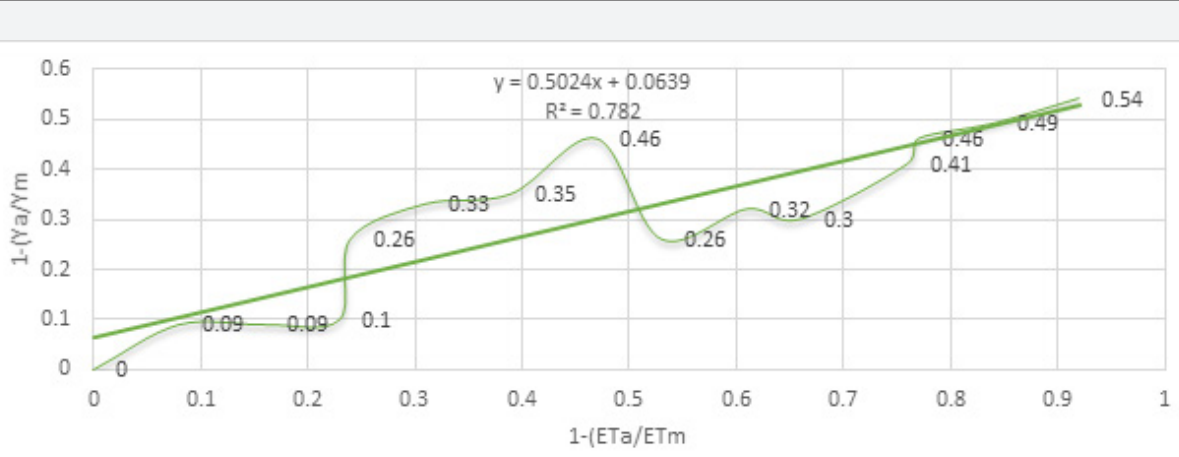

Figure 1: The yield response of water deficit at different growth stage to the yield.

Economic comparison of stage specific moisture stress

The results of economic analysis revealed that, the highest net benefit of 26974.7, 24,874.7 and 24,516.7 ETB/ha obtained from irrigating all growth stage, irrigating all stage except initial and irrigating all stage except initial and maturity stage, respectively with a marginal rate of return (MRR) of 232.9, 20.76 and 849.54\%. Data in Table 4 showed that, the MRR at irrigating all growth stage and irrigating all growth stage except initial and maturity was greater than 50\% MRR showed an economically feasible.
The MRR is below $50 \%$ at irrigating all stage except initial stage even though the net benefit obtained from the treatment is high. Sensitivity analysis of irrigation method relative to $10 \%$ increase in the cost of water and labor as well as $10 \%$ loss due to different post-harvest problem, transportation and storage the MRR remains above the acceptable range. This depict relative advantage and stability of economic benefits due to the irrigation method in the production of common bean in Jimma and other similar area.

Table 4: Economic analysis of common bean grain yield production under different irrigation.

\begin{tabular}{|c|c|c|c|c|c|c|c|c|}
\hline Treatments & $\begin{array}{l}\text { Mean Yield } \\
\text { (K.g/ha) }\end{array}$ & $\begin{array}{c}\text { Adjusted } \\
\text { Yield (K.g/ha) }\end{array}$ & $\begin{array}{l}\text { Gross Benefit } \\
\text { (ETB/ha) }\end{array}$ & $\begin{array}{l}\text { Cost of Irrigation } \\
\text { Water (ETB/ha) }\end{array}$ & $\begin{array}{l}\text { Labor Cost } \\
\text { (ETB/ha) }\end{array}$ & $\begin{array}{l}\text { Gross Cost } \\
\text { (ETB/ha) }\end{array}$ & $\begin{array}{l}\text { Net Benefit } \\
\text { (ETB/ha) }\end{array}$ & MRR (\%) \\
\hline 1 & 2087.7 & 1878.9 & 33820.8 & 454.4 & 6391.7 & 6846.1 & 26974.7 & 232.19 \\
\hline 2 & 1902.2 & 1712.0 & 30816.3 & 416.7 & 5525.0 & 5941.7 & 24874.7 & 20.76 \\
\hline 3 & 1613.5 & 1452.2 & 26139.0 & 334.4 & 4441.7 & 4776.1 & 21362.9 & D \\
\hline 4 & 1554.0 & 1398.6 & 25175.0 & 256.7 & 4441.7 & 4698.3 & 20476.7 & D \\
\hline 5 & 1792.7 & 1613.5 & 29042.3 & 355.6 & 4766.7 & 5122.2 & 23920.1 & D \\
\hline 6 & 1398.9 & 1259.0 & 22662.0 & 296.6 & 3575.0 & 3871.6 & 18790.4 & D \\
\hline 7 & 1525.3 & 1372.8 & 24709.5 & 218.9 & 3575.0 & 3793.9 & 20915.6 & 19.53 \\
\hline 8 & 1773.7 & 1596.4 & 28734.5 & 317.8 & 3900.0 & 4217.8 & 24516.7 & 849.54 \\
\hline 9 & 1135.7 & 1022.1 & 18397.6 & 136.7 & 2491.7 & 2628.3 & 15769.3 & $\mathrm{D}$ \\
\hline 10 & 1366.1 & 1229.4 & 22130.1 & 235.6 & 2816.7 & 3052.2 & 19077.8 & D \\
\hline 11 & 1464.8 & 1318.3 & 23730.0 & 157.7 & 2816.7 & 2974.4 & 20755.6 & 325.52 \\
\hline 12 & 1058.7 & 952.8 & 17150.9 & 98.9 & 1625.0 & 1723.9 & 15427.1 & 82.61 \\
\hline 13 & 1127.8 & 1015.0 & 18270.2 & 197.8 & 1950.0 & 2147.8 & 16122.4 & $\mathrm{D}$ \\
\hline 14 & 1227.3 & 1104.5 & 19881.5 & 120.0 & 1950.0 & 2070.0 & 17811.5 & 688.94 \\
\hline 15 & 966.5 & 869.8 & 15656.6 & 38.9 & 866.7 & 905.6 & 14751.0 & D \\
\hline \multicolumn{9}{|c|}{ Sensitivity Analysis } \\
\hline Treatments & $\begin{array}{l}\text { Mean Yield } \\
\text { (K.g/ha) }\end{array}$ & $\begin{array}{l}\text { Adjusted Yield } \\
\text { (K.g/ha) }\end{array}$ & $\begin{array}{l}\text { Gross Benefit } \\
\text { (ETB/ha) }\end{array}$ & $\begin{array}{l}\text { Cost of Irrigation } \\
\text { Water (ETB/ha) }\end{array}$ & $\begin{array}{l}\text { Labor Cost } \\
\text { (ETB/ha) }\end{array}$ & $\begin{array}{c}\text { Gross Cost } \\
(+10 \%)(\text { ETB } / \mathrm{ha})\end{array}$ & $\begin{array}{c}\text { Net Benefit } \\
(-10 \%)(\text { ETB/ha) }\end{array}$ & MRR (\%) \\
\hline 1 & 2087.7 & 1878.9 & 33820.8 & 454.4 & 6391.7 & 7530.7 & 24277.21 & 189.97 \\
\hline 2 & 1902.2 & 1712.0 & 30816.3 & 416.7 & 5525.0 & 6535.8 & 22387.19 & 16.99 \\
\hline 3 & 1613.5 & 1452.2 & 26139.0 & 334.4 & 4441.7 & 5253.7 & 19226.59 & D \\
\hline
\end{tabular}




\section{International Journal of Environmental Sciences \& Natural Resources}

\begin{tabular}{|c|c|c|c|c|c|c|c|c|}
\hline 4 & 1554.0 & 1398.6 & 25175.0 & 256.7 & 4441.7 & 5168.2 & 18429.02 & $\mathrm{D}$ \\
\hline 5 & 1792.7 & 1613.5 & 29042.3 & 355.6 & 4766.7 & 5634.5 & 21528.05 & $\mathrm{D}$ \\
\hline 6 & 1398.9 & 1259.0 & 22662.0 & 296.6 & 3575.0 & 4258.8 & 16911.33 & $\mathrm{D}$ \\
\hline 7 & 1525.3 & 1372.8 & 24709.5 & 218.9 & 3575.0 & 4173.3 & 18824.05 & 15.98 \\
\hline 8 & 1773.7 & 1596.4 & 28734.5 & 317.8 & 3900.0 & 4639.6 & 22065.06 & 695.08 \\
\hline 9 & 1135.7 & 1022.1 & 18397.6 & 136.7 & 2491.7 & 2891.2 & 14192.36 & $\mathrm{D}$ \\
\hline 10 & 1366.1 & 1229.4 & 22130.1 & 235.6 & 2816.7 & 3357.4 & 17170.05 & $\mathrm{D}$ \\
\hline 11 & 1464.8 & 1318.3 & 23730.0 & 157.7 & 2816.7 & 3271.8 & 18680.01 & 266.34 \\
\hline 12 & 1058.7 & 952.8 & 17150.9 & 98.9 & 1625.0 & 1896.3 & 13884.35 & 67.59 \\
\hline 13 & 1127.8 & 1015.0 & 18270.2 & 197.8 & 1950.0 & 2362.6 & 14510.18 & $\mathrm{D}$ \\
\hline 14 & 1227.3 & 1104.5 & 19881.5 & 120.0 & 1950.0 & 2277.0 & 16030.39 & 563.68 \\
\hline 15 & 966.5 & 869.8 & 15656.6 & 38.9 & 866.7 & 996.1 & 13275.92 & $\mathrm{D}$ \\
\hline
\end{tabular}

\section{Conclusion and Recommendation}

Moisture stresses are among rapidly increasing constraints to agricultural production particularly for short season grain legume crops such as common bean. Moisture stress levels no matter of the degree of its severity has the capacity to affect/ reduce plant height, above ground dry biomass and finally yield at different growing stages. These results indicate that when stress is imposed at initial and late stage of plant development, the effect is low because the plants are already well developed, and they can modify themselves to cope with stress compared to the case when stress is imposed at development and mid-season stages. Hence for maximum grain yield and above ground dry biomass yield to be achieved moisture stress at development and mid-season stage must be avoided. Therefore, it can be concluded that imposing moisture stress at initial and maturity stage was not significantly reduced the commo bean grain yields and dry biomass yield production.

The least water productivity was obtained from the control (full irrigated plot). It is important to note that, except the control, all watering events involved a minimum of one water stress stage. The maximum water productivity was obtained from irrigating only initial stage, even if water saving and water productivity enhancement potential of such practices are high, the level of yield reductions is intolerably high. Irrigating common bean during development, mid-season, maturity stages and skipping irrigation during initial stages resulted the least yield reduction followed by irrigating all stage except initial and maturity. The success of this practice, however, depends upon well establishment of the seedlings before the treatments commence. The crop was found to be sensitive to water stress during development and mid-season stage. As the water demand during these stages is high, stressing during these growth stages was found to result high water saving and water productivity. However, the high yield reduction makes this option of imposing the crop to water stress during bulb formation stage unattractive. The better water productivity without a significant yield reduction was obtained from irrigating only crop development and mid-season stage. The economic analysis revealed that application of water at development and mid-season stage gave maximum net benefit with highest MRR for moisture stress scenario and application of water on all growth stage gave the highest net benefit with better MRR for no moisture stress scenario. Therefore, in area where irrigation water is scarce one can use with holding irrigation water at initial and maturity stage strategy to save considerable amount of water, but the water resource is not scarce application of full crop water requirement is recommended.

\section{Acknowledgment}

The Authors are thankful to staff of Jimma Agricultural Research Center in general for providing necessary support to conduct the study. Our special thanks also go to Ethiopian Institute of Agricultural Research (EIAR) for financial support of the study.

\section{References}

1. COAG (2007) Agriculture and Water Scarcity: A Programmatic Approach to Water Use Efficiency and Agricultural Productivity Comparing notes on institutions and policies. International Water Management Institute, Colombo, Sri Lanka.

2. Emam Y, Shekoofa A, Salehi F, Jalali AH (2010) Water stress effects on two common bean cultivars with contrasting growth habits. AmericanEurasian Journal of Agriculture and Environmental Science 9(5): 495499.

3. Jaleel CA, Manivannon P, Wahid A, Farooq M, HJ Al-Juburi, et al (2009) Drought Stress in Plants: A Review on Morphological and Characteristics. International Journal of Agriculture \& Biology 11(1): $1-6$.

4. Man D, Bao, Y Han (2011) Drought tolerance associated with proline and hormone metabolism in two Fescue cultivars. Hort Sci 46(7): 1027-1032.

5. Jones HG, Corlett JE (1992) Current topics in drought physiology. Journal of Agricultural Science 119: 291-296.

6. Nielsen DC, Nelson NO (1998) Black bean sensitivity to water stress at various growth stages. Crop Science 38(2): 422-427.

7. Molina JC, Moda Cirino V, Júnior NSD, De Faria RT, Destro D (2001) Response of common bean cultivars and lines to water stress. Crop Breed Applied biotechnology 1(4): 363-372.

8. Boutraa T, Sanders FE (2001) Influence of water stress on grain yield and vegetative growth of two cultivars of bean (Phaseolus vulgaris L). J Agronomy and crop science 187(4): 251-275.

9. Michael A (2008) Irrigation Theory and Practice. Indian Agriculture Research Institute, New Delhi, India pp. 427-429. 
10. SAS Institute (1996) SAS/User's Guide, Release 6.03 ed., SAS Inst, Cary, NC, USA.

11. CIMMYT (1988) from Agronomic data to farmer recommendations: An economics training manual. Completely revised edition, Mexico, DF, US.

12. Nepomuscene Ntukamazina, Richard N Onwonga, Rolf Sommer, Clare M Mukankusi, John Mburu, et al. (2017) Effect of excessive and minimal soil moisture stress on agronomic performance of bush and climbing bean (Phaseolus vulgaris L). Cogent Food \& Agriculture 3(1).

13. Amri M, El Ouni MH, Salem MB (2014) Waterlogging affect the development, yield and components, chlorophyll content and chlorophyll fluorescence of six bread wheat genotypes (Triticum aestivum L). Bulgarian Journal of Agricultural Science 20(3): 647-657.

14. Elias Meskelu, Mulugeta Mohammed, Tilahun Hordofa (2014) Response of Maize (Zea mays L.) for Moisture Stress Condition at Different Growth Stages. International Journal of Recent Research in Life Sciences (IJRRLS) 1(1): 12-21

15. Robel Admasu, Minda Tadesse, Tesfaye Shimbir (2018) Effect of Growth Stage Moisture Stress on Maize (Zea Mays L) Yield and Water Use Efficiency at West Wellaga, Ethiopia. Journal of Biology, Agriculture and Healthcare $7(23)$.

16. Ahmad Sher, Lorenzo Barbanti, Muhammad Ansar, Muhammad Azim Malik (2013) Growth response and plant water status in forage sorghum (Sorghum bicolor L) Moench cultivars subjected to decreasing levels of soil moisture. Australian Journal of Crop Science AJCS 7(6): 801-808.

17. Metwally AK (2011) Effect of Water Supply on Vegetative Growth and Yield Characteristics in Onion (Allium Cepa L). Australian Journal of Basic and Applied Sciences 5(12): 3016-3023.

18. Serna RR, Shibata JK, Gallegos JAA, Lopez J, Ortiz Cereceres JD, et al. (2004) Biomass distribution, maturity acceleration and yield in drought-stressed common bean cultivars. Field Crops. Research 85(23): 203-211.

19. Barrios AN, Hoogenboom G, Nesmith DS (2005) Drought stress and the distribution of vegetative and reproductive traits of a bean cultivar. Scientia Agricola 62(1): 18-22.
20. Ambachew D, Mekbib F, Asfaw A, Beebe SE, Blair MW (2015) Trait associations in common bean genotypes grown under drought stress and field infestation by BSM bean fly. The Crop Journal 3(4): 305-316.

21. Darkwa K, Ambachew D, Mohammed H, Asfaw A, Blair MW (2016) Evaluation of common bean (Phaseolus vulgaris L) genotypes for drought stress adaptation in Ethiopia. The Crop Journal 4(5): 367-376.

22. RG Bhagyawant, SD Gorantiwar, SD Dahiwalkar (2015) Effect of Deficit Irrigation on Crop Growth, Yield and Quality of Onion under Surface Irrigation. American Eurasian J Agric \& Environ Sci 15(8): 1672-1678.

23. Temesgen T, Ayana M, Bedadi B (2018) Evaluating the Effects of Defcit Irrigation on Yield and Water Productivity of Furrow Irrigated Onion (Allium cepa L.) in Ambo, Western Ethiopia. Irrigat Drainage Sys Eng 7: 203.

24. Yanqi Wei, Juliang Jin, Shangming Jiang, Shaowei Ning, Li Liu (2018) Quantitative Response of Soybean Development and Yield to Drought Stress during Different Growth Stages in the Huaibei Plain, Agronomy, China. Agronomy 8(7): 97.

25. Liu F, Christian, R Jensen, CR, Andersen MN (2008) Effects of drought and salt stress during early reproductive growth stages in faba bean and quinoa. IOP Conference Series: Earth and Environmental Science 6(37).

26. Kirda C, Kanber R, Tulucu K (1999) Yield response of cotton, maize, soybean, sugar beet, sunflower and wheat to deficit irrigation. In: $\mathrm{C}$ Kirda, P Moutonnet, C Hera, DR Nielsen (Eds.), Crop yield response to deficit irrigation. Kluwer Academic Publishers. Dordrecht, The Netherlands.

27. Ali MH, Talukder MSU (2008) Increasing water productivity in crop production-a synthesis. Agricultural water management 95(11): 1201-1213.

28. RA Bustomi Rosadi, Afandi Masateru Senge Kengo Ito, John T Adomako (2007) The effect of water stress in regulated deficit irrigation on soybean yield (Glycine max [L.] Merr.). Paddy Water Environ 5(3): 163-169.

29. Kirda C (2002) Deficit irrigation scheduling based on plant growth stages showing water stress tolerance. FAO, Rome, Italy.

\section{Your next submission with Juniper Publishers} will reach you the below assets

- Quality Editorial service

- Swift Peer Review

- Reprints availability

- E-prints Service

- Manuscript Podcast for convenient understanding

- Global attainment for your research

- Manuscript accessibility in different formats

(Pdf, E-pub, Full Text, Audio)

- Unceasing customer service

Track the below URL for one-step submission https://juniperpublishers.com/online-submission.php 
